\title{
Managing Vineyard Topography and Seasonal Variability to Improve Grape Quality and Vineyard Sustainability
}

\author{
Elena Mania ${ }^{1}$, Fabio Petrella ${ }^{2}$, Matteo Giovannozzi ${ }^{2}$, Mauro Piazzi ${ }^{3}$, Alena Wilson ${ }^{1}$ and Silvia Guidoni $^{1, *(D)}$ \\ 1 Department of Agricultural, Forest and Food Sciences, Università degli Studi di Torino, Largo Braccini 2, \\ 10095 Grugliasco, Italy; elena.mania83@gmail.com (E.M.); alenaelizabeth.wilson@unito.it (A.W.) \\ 2 IPLA S.p.A., Corso Casale 476, 10132 Torino, Italy; petrella@ipla.org (F.P.); giovannozzi@ipla.org (M.G.) \\ 3 Timesis Srl, Via Niccolini 7, 56017 San Giuliano Terme, Italy; mauro.piazzi@timesis.it \\ * Correspondence: silvia.guidoni@unito.it
}

check for

updates

Citation: Mania, E.; Petrella, F.; Giovannozzi, M.; Piazzi, M.; Wilson, A.; Guidoni, S. Managing Vineyard Topography and Seasonal Variability to Improve Grape Quality and Vineyard Sustainability. Agronomy 2021, 11, 1142. https://doi.org/ 10.3390/agronomy11061142

Academic Editors: Federica Gaiotti and Chiara Pastore

Received: 3 May 2021

Accepted: 29 May 2021

Published: 3 June 2021

Publisher's Note: MDPI stays neutral with regard to jurisdictional claims in published maps and institutional affiliations.

Copyright: (c) 2021 by the authors. Licensee MDPI, Basel, Switzerland. This article is an open access article distributed under the terms and conditions of the Creative Commons Attribution (CC BY) license (https:/ / creativecommons.org/licenses/by/ $4.0 /)$.

\begin{abstract}
Topography may induce variability in meteorological conditions at the meso-scale level and could influence grape quality. Understanding the impact of topography on grape ripening allows for the development of sustainable management practices that include topographical influences in their consideration. This is also important for applying proactive strategies able to counter the expected changes of climate. This study was conducted on cv. Nebbiolo vineyards in North-West Italy. The topographic traits were performed in 17 vineyards within the region, which had previously been identified as belonging to different terroir units. An analysis of historical meteorological data series was also carried out to characterize the units from the meteorological point of view. The grape composition was investigated during 2012 and 2013. Based on the topography traits, a Cluster Analysis classified the 17 vineyards into four groups. Differences among groups mainly concerned insolation and heat accumulation. Topography influenced the individual components of grape quality differently depending on the seasonal weather trend. Interactions between topography and vintage were observed for a few parameters. Better understanding the grapevine reaction to external factors/site characteristics can allow for improved site and season-specific management decision making and can contribute to improving vineyard sustainability while maintaining winery objectives and wine typicity.
\end{abstract}

Keywords: intercepted surface solar radiation (insolation); slope aspect; temperature and rainfall time series; grape quality; anthocyanin; Nebbiolo; terroir; climate change; vineyard management; sustainability

\section{Introduction}

Winegrowing areas are characterized by different landforms. In Italy, more than 50\% of viticulture is located in hilly areas; in these conditions, high topo-climatic heterogeneity in terms of exposure, elevation, and slope is evident [1]. The heterogeneity of the land morphology creates unique and complex landforms that can influence berry ripening and can require specific knowledge to carefully manage with suitable agronomic choices. The need to improve the sustainability of agriculture and reduce the impact of climate change [2] further complicates the farmer's decision-making process. Climate elements (temperature, rainfall, etc.), soil features (parent material, soil evolution and composition, etc.) and site topography (i.e., slope aspect, elevation, etc.) of an individual geographic area, that often is individuated as a "terroir", justify specific management choices over time. Among these choices, slope settling, soil management practices, training systems, choice of variety and rootstock, winemaking techniques, and oenological objectives are the most important [3,4]. It is difficult to investigate the synergistic influence exerted by all these factors on grape and wine composition [1]. Recent studies statistically examined the potentiality of soil and topo-climatic variables for winegrowing area zoning $[5,6]$. Other studies also concerned the influence of topography on grape ripening and composition [7-10]. The climate variability within a vineyard at a meso or micro scale has been studied [11-14] also evidencing 
its relationship with grape ripening [15-17]. The interaction between the environment, soil characteristics (e.g., texture and lithological origin), and cultural choices (e.g., row orientation and soil management) may influence the interception of solar radiation, soil water holding capacity, and the microclimate of a vineyard, and vines [16,18-22]. These factors, in turn, can influence vine vigor and productivity as well as ripening processes and grape composition $[7,8,11,23-31]$. In two studies conducted in flat vineyards at different elevations in Mediterranean climates, air temperature and canopy exposure to sunlight, and therefore vine photosynthetic efficiency, depended on row orientation [22] and vineyard elevation [8]. Hunter et al. [22] did not observe differences in terms of hourly mean temperature, between NW-SE and NE-SW row orientations, while the E canopy side of $\mathrm{N}-\mathrm{S}$ row orientation achieved the highest temperature during the morning. Similar behaviour was observed in hilly vineyards facing east, while temperatures peaked in the afternoon in west facing vineyards [32]. From another study conducted in the Barolo region, it emerged that in south-facing vineyards air temperature above the canopy varied inversely according to their elevation, whereas in terms of heat accumulation (calculated as Growing Degree Days) west facing vineyards were cooler than those facing south $[12,28,29]$. Furthermore, the correlation between berry temperature and air temperature depended on the vineyard aspect [32]. Because berry temperature may hugely affect biosynthesis and degradation of primary and secondary metabolites in the berries [33-40], vineyard aspect and elevation, which may influence berry temperature, may also influence berry composition $[28,29,32,41,42]$. In a study carried out in 18 vineyards of the Douro region (Portugal) growing cv. Touriga National, a significant influence of vineyard elevation and slope aspect on vine behaviour and grape quality emerged [43]. In particular, the lowest yield and berry mass and the highest anthocyanin concentration were found in the vineyards at higher elevation with a SW aspect. In Switzerland, a study performed on 23 plots of $\mathrm{cv}$. Chasselas confirmed the influence of elevation on the precocity of phenological stages with the vineyards at higher elevation being the latest ripening plots [44]. Moreover, the latest ripening plots accumulated the highest amount of soluble solids per berry. The highest sugar concentrations were achieved in the less vigorous plots that also received the highest potential solar radiation regardless of altitude. This was in agreement with the findings of a recent study conducted in South Tirol (northern Italy) that revealed a direct relationship between the must sugar content and a "Solar Radiation Identity index". This last also showed to be a useful descriptor of the vineyard topo-climate [7]. Although vineyard aspect and elevation influence the vineyard microclimate and grape ripening, the vintage might exhibit greater effects on metabolic composition of grape berry and grape must than the effects of topographical variables [45-47].

Improving the understanding of the influence of topography on grape ripening processes is an important undertaking to develop viticultural management practices that include topographical influences in their consideration. This understanding is also important for implementing precision management practices that can contribute to the enhancement of the growing environment and grape quality while in the longer term aiming to reduce the impacts of climate change $[2,48]$. The aim of this work was to further understand the role of the topographic elements on climate at a meso-scale level, and on berry ripening and composition in an extremely hilly wine growing region.

\section{Material and Methods}

The study was carried out in 2012 and 2013 in the hilly winegrowing area of Langhe (North-West Italy) that is situated on marine grey marls (Marne di Sant'Agata Fossili) [49]. This is an intensively cultivated area, where elevation, gradient and aspect of the slopes vary considerably due to the heterogeneity of the territory. Here, viticulture covers most of the cultivated surface, thus it is strongly linked to the landscape and to the local economy. The study was conducted on vineyards belonging to the hilly premium wine growing region where "Barolo DOCG" wine is produced (Figure 1). 


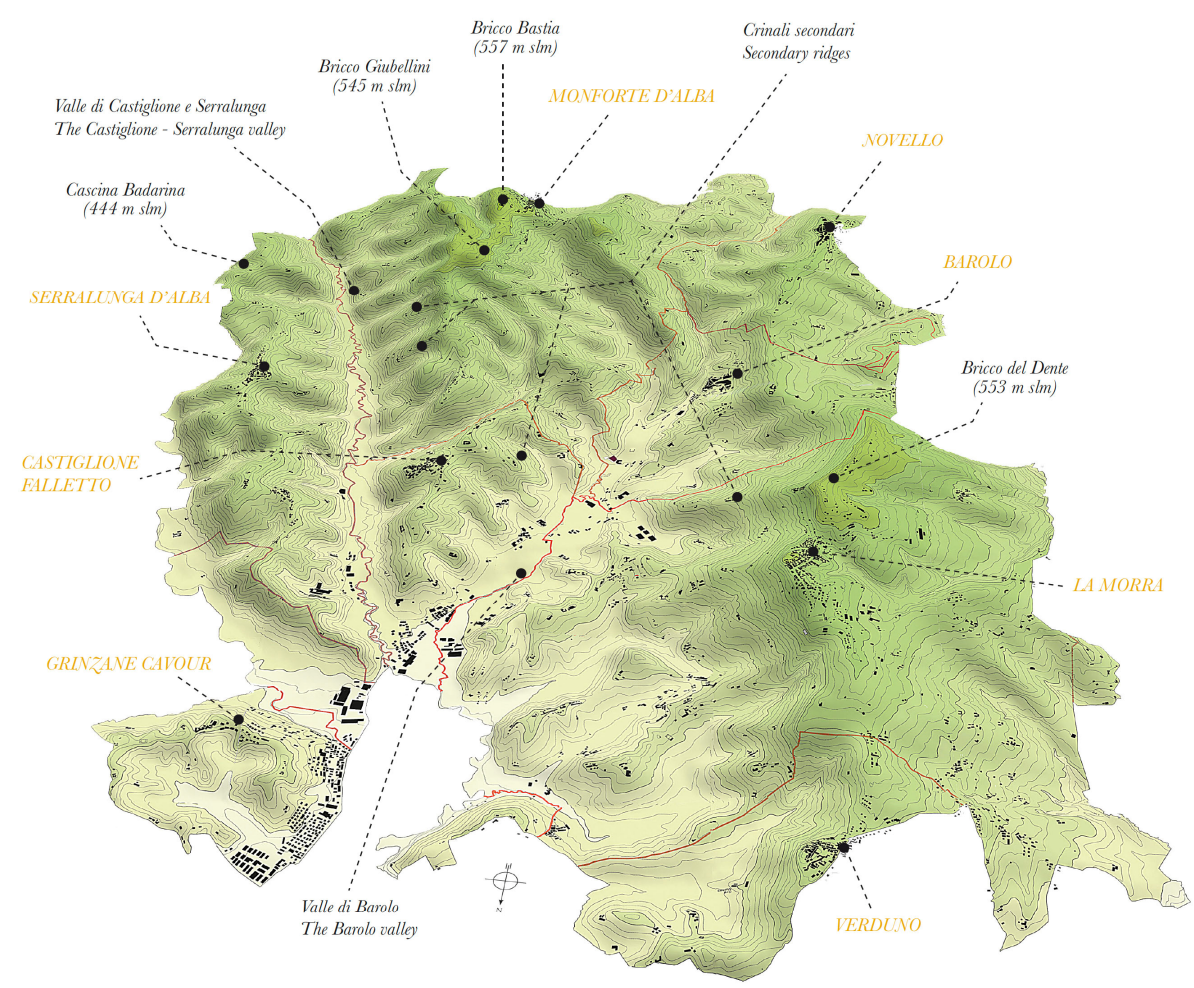

Figure 1. The study area (about 8000 ha) includes 2100 ha of vineyards planted with cv. Nebbiolo for the production of the premium wine "Barolo DOCG. Figure courtesy of Alessandro Masnaghetti Editore ENOGEA [50].

\subsection{Climatic Conditions of the Area and Seasonal Trend of Temperature and Rainfall}

Following the Köppen-Geiger classification, the climate of the area (coordinates of the Barolo village: $44^{\circ} 36^{\prime} 42^{\prime \prime} 84 \mathrm{~N} 07^{\circ} 56^{\prime} 38^{\prime \prime} 04 \mathrm{E}$ ) is warm temperate, humid with hot summers (Cfa) (http:/ / koeppen-geiger.vu-wien.ac.at/, accessed on 15 May 2021) [51]. In the area five public weather stations belonging to the Regional AgroMeteorological survey system (RAM) were present. They were located at: Serralunga Boscareto (SB) (405 m above sea level, a.s.1.), La Morra (LM) (326 m a.s.1.), Castiglione Falletto (CF) (309 m a.s.1.), Barolo (B) (360 $\mathrm{m}$ a.s.1.), and Serralunga Fontanafredda (FF) (309 $\mathrm{m}$ a.s.1.). To synthetically describe the winegrowing area from a climatic point of view, the average minimum, maximum and mean temperatures, the average annual accumulation of Growing Degree Days (GDD, base temperature $10^{\circ} \mathrm{C}$ ), and rainfall $(\mathrm{mm})$ were calculated for each of the five stations based on a time series of 14-20 years, depending on the station (readings beginning from 1999 to 2005 and ending in 2018). For every parameter, the average value of each site was then compared to the average value of the area calculated using all the available historical data series. Furthermore, to evaluate the two studied vintages, the annual GDD and rainfall of 2012 and 2013 were calculated for each weather station and compared with the historical average values for that weather station.

\subsection{Vineyard Characteristics}

The area of the study consists of a complex hilly system crossed by two valleys which run from NNE-SSW and NW-SE, respectively, dividing one central and two outer hills (Figure 1). Because of this morphology of tortuous aspects along with a significant slope gradient, vineyard topography varies considerably. In this area, 17 commercial vineyards were selected to represent all the "terroir units" identified during a previous zoning study of the area [52]. The vineyards belonged to different growers but in each of them cv. Nebbiolo was cultivated by vertical shoot positioned trellis system and by Guyot pruning system (8-10 buds/cane). The row orientation was perpendicular to the slope gradient, which is the tradition in this area. Vineyard management was quite similar for all vineyards 
according to the know-how of the area and included yield control by cluster thinning. On average, the vineyards were 20 years old and all of them were planted at a density of 4500 plants/ha. The soil between vines was managed by tillage or chemical weeding; the soil between rows was covered by resident vegetation and tilled in autumn every second year by harrow. In every vineyard, all the field and grape quality assessments were conducted on three replicates of 15 plants each, randomly distributed within the vineyard.

Vineyard topography, specifically elevation, slope aspect and gradient, and geographical coordinates were obtained by a Global Positioning System (GPS) instrument (GARMIN eTrex 20x, Olathe, USA). The intercepted surface solar radiation (insolation) was estimated using the "Area Solar Radiation" tool of ArcGIS Pro 2.1 software (ESRI, Redlands, CA, USA): the average annual insolation was calculated for a circular surface of $60 \mathrm{~m}$ diameter centered in each vineyard.

During the 2012 season, a pedological survey was carried out in each vineyard by a protocol proposed by IPLA [53]. The soils were classified according to the USDA Soil Taxonomy [54]. For each horizon, soil samples were collected and analyzed for texture, $\mathrm{pH}$ in water, calcium carbonate [55], and organic carbon [56]. Soil from the topsoil $(0-20 \mathrm{~cm})$ was also analyzed for nitrogen content and cation exchange capacity (CEC) [55]. Available water capacity (AWC) was calculated on samples from topsoil and from the horizon explored by most of the root system $(30$ to $70 \mathrm{~cm})$ by application of official soil analysis methods $[57,58]$.

\subsection{Field Measurements and Grape Quality}

Seasonal grape ripening evolution, grape quality at harvest, vine vigor, and yield were monitored in both seasons, on 15 vines per replicate. Three consecutive berry samples of 200 berries were collected at 30, 45, and 65 days after veraison (dav); the harvest was made on the 65th dav. Sampled berries were weighed and crushed, and the must analyzed to determine the main technological parameters. Total soluble solids (TSS), $\mathrm{pH}$, and titratable acidity were analyzed by an FT-IR method (WineScan ${ }^{\mathrm{TM}}$, Foss, Denmark). Malic and tartaric acids were measured by HPLC (LC-920 Varian, Palo Alto, CA, USA) equipped with the column Phenomenex Rezex ROA Organic Acid H+, $300 \times 7.8 \mathrm{~mm}, 5 \mu \mathrm{m}$ [59]. Total anthocyanin concentrations were analyzed by spectrometry (Helios Squamate UV-VIS 9423 Aqua 2200E, Thermospectronic, Waltham, MA, USA) [60-62]. At harvest the number of bunches per plant was counted and the yield was weighed with a dynamometer (KERN HCB 20K10, KERN \& Sohn GmbH, Germany); then the average weight per cluster was calculated. At winter pruning, the shoot number per plant was counted and the pruning weight was measured with the dynamometer; the average weight per shoot and the Ravaz index were then calculated.

\subsection{Statistical Analysis}

A grouping of the 17 vineyard sites was performed by Cluster Analysis (CA) calculated on slope $\left(^{\circ}\right)$, aspect $\left({ }^{\circ}\right)$, elevation (m a.s.l.), and insolation $\left(\mathrm{kW} \mathrm{h} \mathrm{m}^{-2}\right)$. After grouping the vineyards based on CA results, a one-, or two-way ANOVA was carried out on vine and grape quality parameters, using "sampling date", "group", and "year" as factors to determine if differences existed among the groups. Before proceeding with the ANOVA, normal distribution of the data (Shapiro-Wilk test) and homogeneity of the variances (Levene test) were verified. Significant differences among groups were determined by the Duncan test at a significance level of 5\%. A Principal Component Analysis (PCA) was carried out on quality berry variables (berry weight, Total Soluble Solids (TSS), Total Acidity (TA), pH, malic acid, and anthocyanin concentration) at harvest. Statistical analyses were performed using SAS 9.4 software (SAS Institute Inc., Cary, NC, USA). 


\section{Results}

\subsection{Development of Mesoclimatic Units and Weather Conditions of the Study Years}

The mean annual temperature $\left(13.3^{\circ} \mathrm{C}\right.$, ranging from 12 to $\left.14.2^{\circ} \mathrm{C}\right)$, rainfall $(800 \mathrm{~mm}$, ranging from 488 to $1250 \mathrm{~mm}$ ) and seasonal accumulation of GDD were calculated based on data from all five weather stations over about 20 years. The average values and seasonal accumulation of GDD and rainfall significantly differed depending on the weather station location (Figure 2). Serralunga Boscareto (SB) and La Morra (LM) accumulated the highest and the lowest seasonal GDD, respectively. An intermediate situation was observed for Barolo (B), Serralunga Fontanafredda (SF) and Castiglione Falletto (CF) where the seasonal pattern and annual total amounts were similar to each other and to the GDD average calculated for the whole area (Figure 2a). Rainfall volumes were greater in LM; while the other stations registered similar average values and accumulation patterns (Figure 2b). Due to these observations of historical weather conditions, the area of study was divided into three mesoclimatic units (MU) corresponding to SB, LM, and B (which included SF and $C F$ ). Weather related data recorded from the respective weather stations were used to describe each MU from the climatic point of view, and the weather conditions of the two years of the study, 2012 and 2013 (when berry sampling occurred), which was then compared to the long-term averages.
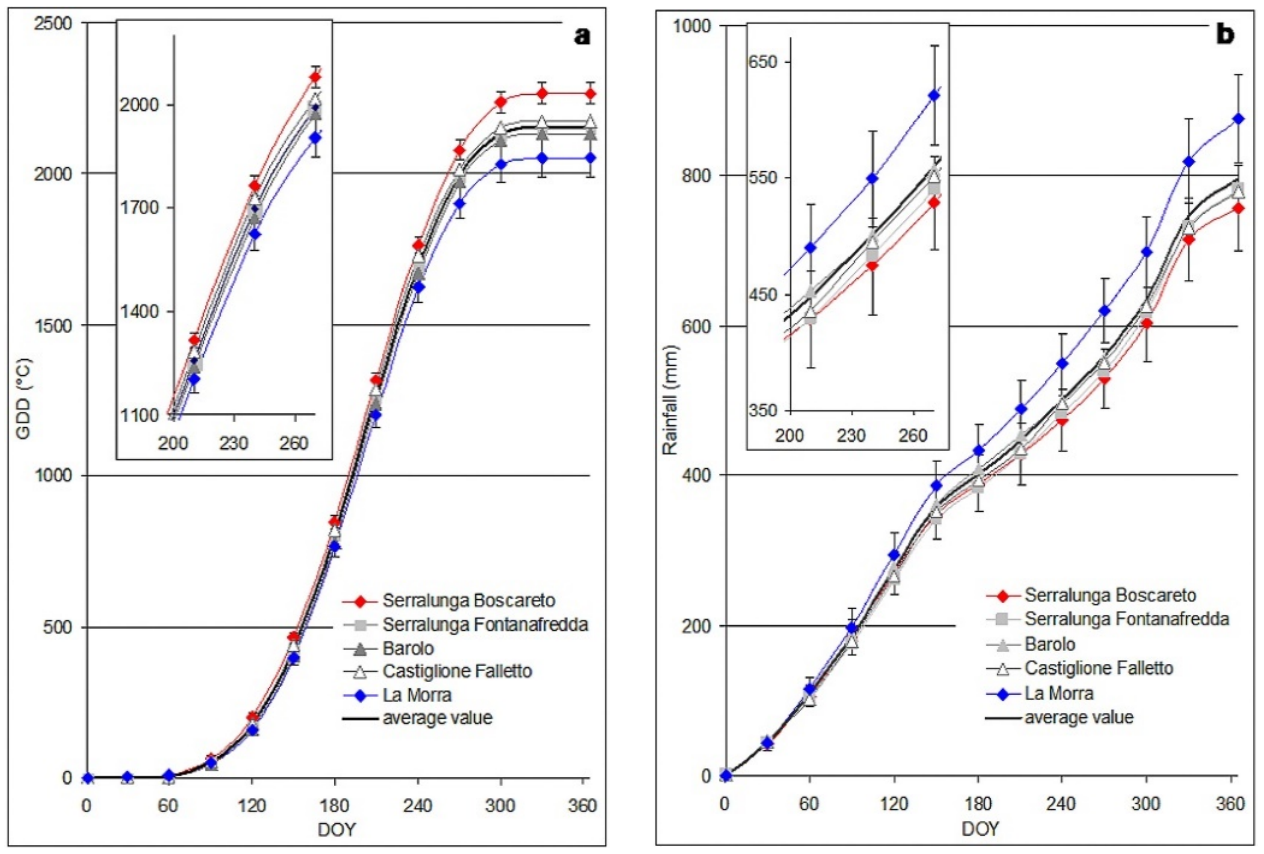

Figure 2. Yearly cumulated growing degree days (GDD, a) and rainfall (mm, b) calculated for the five weather stations of the area and average value for the whole area. Lines are the mean values of 20 year-observations for Castiglione Falletto and Serralunga Fontanafredda, 19 years for La Morra, 16 years for Barolo, and 14 years for Serralunga Boscareto. In the insert, the enlarged details of the period between veraison (Julian day 210) and harvest (Julian day 275) are shown. Data of Figures 2 and 3 were recorded by Piedmont Agrometeorological Network, Agrometeorology Section of Agriculture Department-Regione Piemonte (www.sistemapiemonte.it/agricoltura/ram/, accessed on 15 May 2021). 


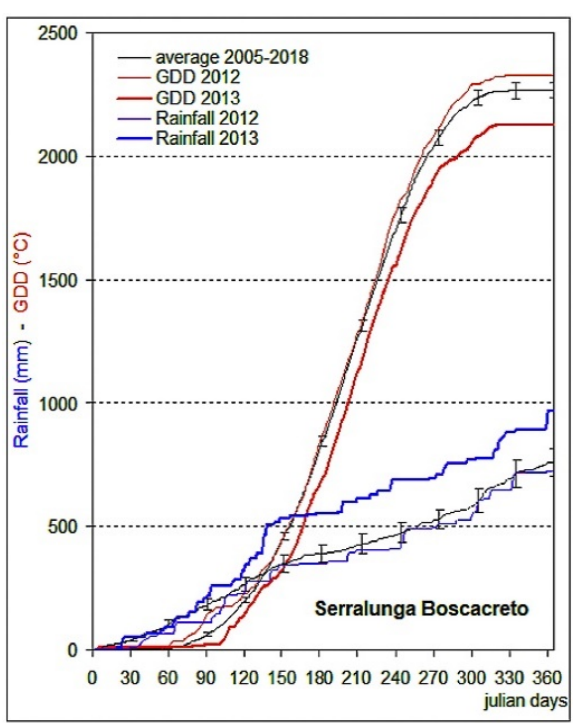

(a)

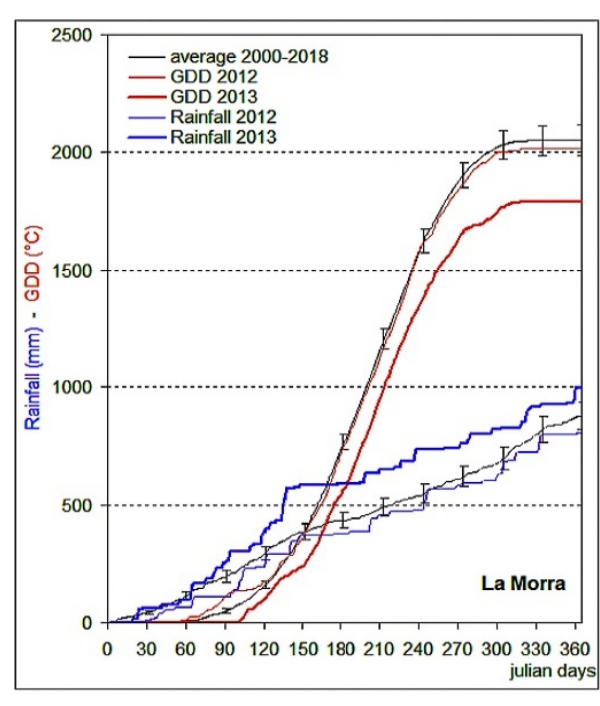

(b)

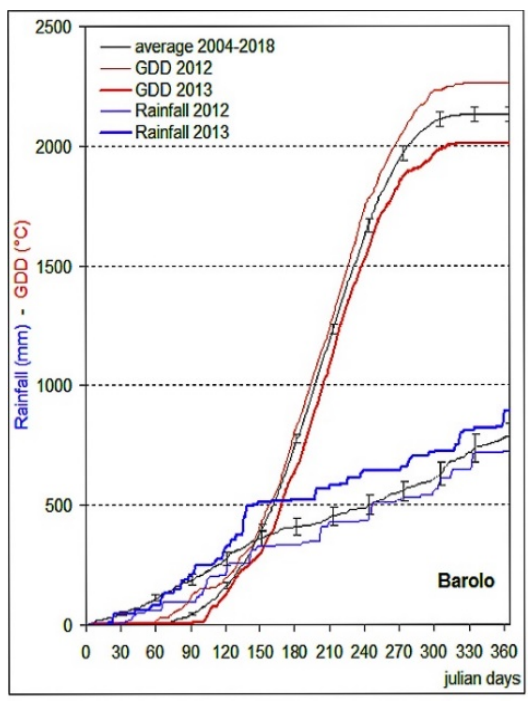

(c)

Figure 3. Yearly cumulated growing degree days (GDD, ${ }^{\circ} \mathrm{C}$-red lines) and rainfall (mm, blue lines) of 2012, 2013 (bold lines), and average values of the time series of both parameters (black lines) \pm standard errors, calculated for the sites used as a reference for the three mesoclimatic units in the study area. Average values were calculated for 14 years for Serralunga Boscareto (SB, a), 19 years for La Morra (LM, b), and 15 years for Barolo (B, c).

In both years, the highest GDD was recorded in SB, the lowest in LM (Figure 3). Furthermore, the 2012 values in LM did not differ from the local average of the 1999-2018 series; however, in SB and B, the GDD were higher than the average of their respective time series (of 14 and 16 years, respectively). In 2013, all GDD's were lower than 2012 GDD's and lower than the time series averages, particularly in LM.; however, the relationships among the stations appeared constant (Figure 3). The average annual rainfall was higher in LM than in SB or B. In 2012, the amount of rainfall did not differ from the average of the time series for any of the three mesoclimatic areas; while in 2013, rainfall was more abundant than the average, especially in early spring, and particularly in SB; in all cases, B was the least rainy MU (Figure 3). Due to its meteorological characteristics, 2013 can be considered an anomalous year.

\subsection{Vineyards Characteristics}

Based on intercepted surface solar radiation, elevation, slope aspect, and gradient (Table 1), the 17 vineyards considered for this study, were grouped into four homogenous groups by a Cluster Analysis and were named after the dominant slope aspect of their group. The vineyards located in the LM unit were separated into groups facing east northeast (E) and east south-east (SE); the vineyards located in the B unit faced west north-west (W), and those located in the SB unit faced south-west (SW) (Figure 4). SE and SW facing vineyards intercepted similar amounts of solar radiation, but SE vineyards were at a lower elevation. $\mathrm{E}$ and $\mathrm{W}$ facing vineyards intercepted the lowest amount of radiation and were at the same elevation (Table 1). 
Table 1. Vineyard codes, urban district, mesoclimatic unit (MU), group membership obtained by cluster analysis, and main topographic features of the vineyards investigated; average values were calculated for each group.

\begin{tabular}{|c|c|c|c|c|c|c|c|}
\hline Code & Urban District & MU & Group & $\begin{array}{c}\text { Aspect } \\
\left({ }^{\circ}\right)\end{array}$ & $\begin{array}{c}\text { Elevation } \\
\text { (m above See } \\
\text { Level) }\end{array}$ & $\begin{array}{l}\text { Slope } \\
\text { Gradient } \\
\left.\quad{ }^{\circ}\right)\end{array}$ & 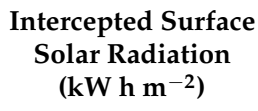 \\
\hline 287 & Castiglione F. & LM & $\mathrm{E}$ & 70 & 313 & 7 & 981 \\
\hline 295 & Verduno & LM & $\mathrm{E}$ & 96 & 365 & 15 & 1137 \\
\hline 296 & Verduno & LM & SE & 82 & 264 & 11 & 1107 \\
\hline 297 & Verduno & LM & SE & 115 & 283 & 20 & 1158 \\
\hline 294 & La Morra & LM & SE & 135 & 217 & 17 & 1195 \\
\hline 293 & La Morra & LM & SE & 165 & 249 & 2 & 1204 \\
\hline 292 & Diano d'Alba & LM & SE & 146 & 274 & 18 & 1223 \\
\hline 283 & Barolo & LM & SE & 148 & 307 & 15 & 1217 \\
\hline 273 & Novello & SB & SW & 190 & 398 & 18 & 1263 \\
\hline 289 & Serralunga & SB & SW & 209 & 384 & 13 & 1238 \\
\hline 291 & Sinio & SB & SW & 190 & 361 & 25 & 1251 \\
\hline 274 & Novello & SB & SW & 235 & 338 & 7 & 1159 \\
\hline 284 & Barolo & B & $\mathrm{W}$ & 279 & 282 & 14 & 1056 \\
\hline 285 & Castiglione F. & B & W & 270 & 252 & 13 & 1095 \\
\hline 286 & Castiglione F. & B & W & 320 & 333 & 14 & 973 \\
\hline 288 & Serralunga & B & W & 305 & 323 & 9 & 1051 \\
\hline 290 & Sinio & B & W & 280 & 432 & 15 & 1054 \\
\hline \multirow{4}{*}{\multicolumn{3}{|c|}{ Mean values of the groups }} & $\mathrm{E}$ & $83 \mathrm{~d}^{1}$ & $339 a b$ & $11.0 \mathrm{a}$ & $1059 \mathrm{~b}$ \\
\hline & & & SE & $132 \mathrm{c}$ & $266 \mathrm{~b}$ & $13.8 \mathrm{a}$ & $1184 \mathrm{a}$ \\
\hline & & & SW & $206 \mathrm{~b}$ & $370 \mathrm{a}$ & $15.8 \mathrm{a}$ & $1228 \mathrm{a}$ \\
\hline & & & W & $291 \mathrm{a}$ & $324 \mathrm{ab}$ & $13.0 \mathrm{a}$ & 1046 b \\
\hline
\end{tabular}

${ }^{1}$ For each column, different letters indicate significant differences among groups at $p \leq 0.05$ according to the Duncan test.

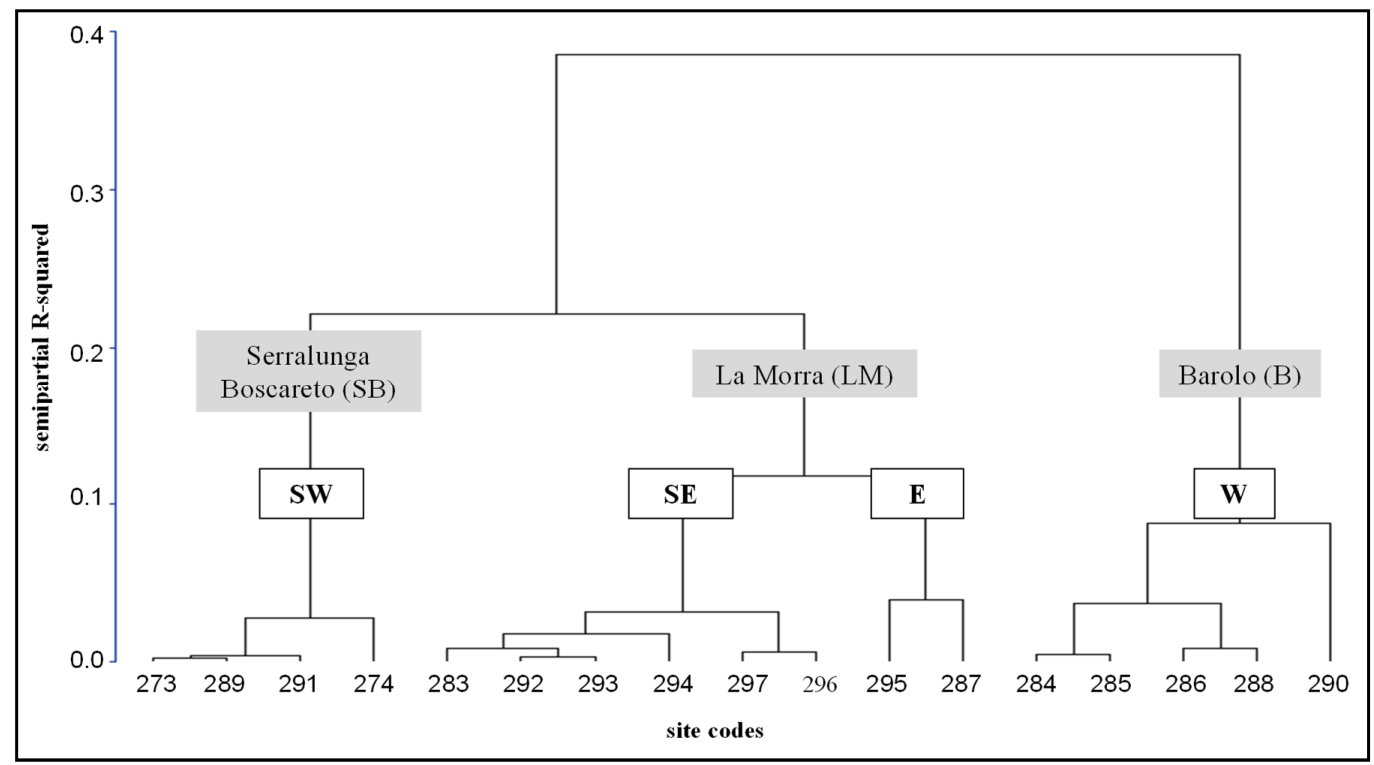

Figure 4. Grouping of the vineyards based on the Cluster Analysis carried out on the geographical variables (i.e., aspect, elevation, slope gradient, and intercepted surface solar radiation), dominant slope aspect of each group and mesoclimatic units to which groups belong are also indicated.

Despite differences among units and groups in terms of topography and climate, the area showed a higher homogeneity with regard to soil and lithological substratum (mainly marly) and soil classification that, in particular, evidenced a low degree of soil evolution for all vineyards (Table 2). Very few differences emerged among groups in terms of the main soil chemical-physical characteristics, both when topsoil and deeper soil horizons were examined (Table 2 and Supplementary Table S1). For these reasons soil characteristics were not considered in the effect on vine growth and grape ripening. 


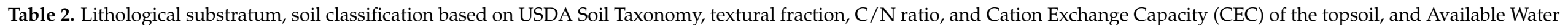
Capacity (AWC) of top and subsoil; average values of the main soil characteristics were calculated for each group.

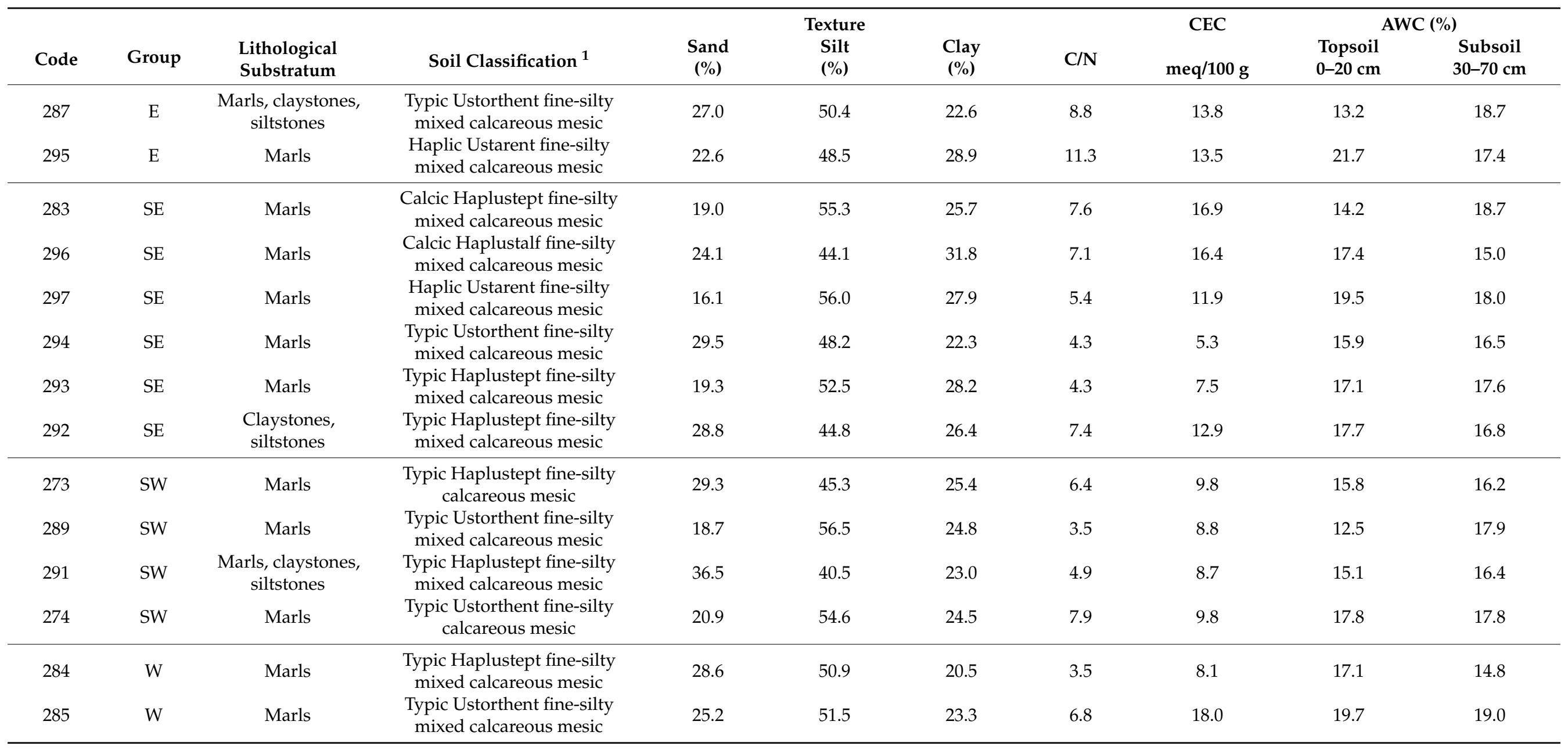


Table 2. Cont.

\begin{tabular}{|c|c|c|c|c|c|c|c|c|c|c|}
\hline \multirow[b]{2}{*}{ Code } & \multirow[b]{2}{*}{ Group } & \multirow[b]{2}{*}{$\begin{array}{l}\text { Lithological } \\
\text { Substratum }\end{array}$} & \multirow[b]{2}{*}{ Soil Classification ${ }^{1}$} & \multirow{2}{*}{\multicolumn{2}{|c|}{$\begin{array}{c}\text { Texture } \\
\text { Silt } \\
(\%)\end{array}$}} & \multirow[b]{2}{*}{$\begin{array}{c}\text { Clay } \\
(\%)\end{array}$} & \multirow[b]{2}{*}{$\mathrm{C} / \mathrm{N}$} & \multirow{2}{*}{$\begin{array}{c}\text { CEC } \\
\text { meq/100 g }\end{array}$} & \multicolumn{2}{|c|}{ AWC (\%) } \\
\hline & & & & & & & & & $\begin{array}{l}\text { Topsoil } \\
0-20 \mathrm{~cm}\end{array}$ & $\begin{array}{r}\text { Subsoil } \\
30-70 \mathrm{~cm}\end{array}$ \\
\hline 286 & $\mathrm{~W}$ & $\begin{array}{l}\text { Marls, claystones, } \\
\text { siltstones }\end{array}$ & $\begin{array}{l}\text { Typic Ustorthent fine-silty } \\
\text { mixed calcareous mesic }\end{array}$ & 19.9 & 54.6 & 25.5 & 6.2 & 13.8 & 18.8 & 17.6 \\
\hline 288 & $\mathrm{~W}$ & Marls & $\begin{array}{l}\text { Typic Haplustept fine-silty } \\
\text { mixed calcareous mesic }\end{array}$ & 19.5 & 51.9 & 28.6 & 5.1 & 13.8 & 17.1 & 16.6 \\
\hline \multirow[t]{5}{*}{290} & $\mathrm{~W}$ & Marls & $\begin{array}{l}\text { Typic Ustorthent fine-silty } \\
\text { mixed calcareous mesic }\end{array}$ & 19.8 & 51.8 & 28.4 & 3.0 & 7.6 & 17.1 & 17.2 \\
\hline & & \multirow{4}{*}{$\begin{array}{l}\text { Mean values of } \\
\text { the groups }\end{array}$} & $\mathrm{E}$ & $24.8 \mathrm{a}^{2}$ & $49.5 \mathrm{a}$ & $25.8 \mathrm{a}$ & $10.1 \mathrm{a}$ & $13.7 \mathrm{a}$ & $17.5 \mathrm{a}$ & $18.1 \mathrm{a}$ \\
\hline & & & SE & $22.8 \mathrm{a}$ & $50.2 \mathrm{a}$ & $27.1 \mathrm{a}$ & $6.0 \mathrm{~b}$ & $11.8 \mathrm{a}$ & $17.0 \mathrm{a}$ & $17.1 \mathrm{a}$ \\
\hline & & & SW & $26.4 \mathrm{a}$ & $49.2 \mathrm{a}$ & $24.4 \mathrm{a}$ & $5.7 \mathrm{~b}$ & $9.3 \mathrm{a}$ & $15.3 \mathrm{a}$ & $17.1 \mathrm{a}$ \\
\hline & & & $\mathrm{W}$ & $22.6 \mathrm{a}$ & $52.1 \mathrm{a}$ & $25.3 \mathrm{a}$ & $4.9 \mathrm{~b}$ & $12.3 \mathrm{a}$ & $18.2 \mathrm{a}$ & $17.0 \mathrm{a}$ \\
\hline
\end{tabular}

1. The suffixes ept, ent, alf refer, respectively, to Inceptisols, Entisols, and Alfisols; ${ }^{2}$ different letters indicate significant differences among groups at $p \leq 0.05$ according to the Duncan test. 
Entisols and Inceptisols were the most widespread soil types, whereas only in one vineyard the soil was an Alfisol (Table 2). Topsoil textures were mainly silty loam without skeleton; the percentage of silt was rarely less than $45 \%$, the percentage of clay was always above $20 \%$ (in most cases over $25 \%$ ), and the percentage of sand averaged $24 \%$ (Table 2 ). The $\mathrm{C} / \mathrm{N}$ ratio was, on average, around six and the Cation Exchange Capacity (CEC) averaged $11.4 \mathrm{meq} / 100 \mathrm{~g}$. No significant differences emerged among groups, regarding topsoil composition and properties, with the exception of the $\mathrm{C} / \mathrm{N}$ ratio which was higher for group $\mathrm{E}$. Available water capacity was similar in both upper and deeper soil layers in every vineyard (Table 2). The soil was alkaline at every site and horizon: $\mathrm{pH}$ values ranged from 7.8 to 8.7 and the average percentage of calcium carbonate was $21.7 \%$. The differences identified in the subsoil properties were not consistent with the vineyard groupings (Supplementary Table S1).

\subsection{Berry/Must Parameters}

Year, group, and sampling date influenced berry and must parameters (Table 3). On average, berry size was larger and must total soluble solids, titratable acidity, malic acid, and anthocyanins concentration were higher in 2013 than in 2012, whereas $\mathrm{pH}$ and tartaric acid concentration were lower (Table 3). Regardless of date and year, berry weight varied depending on vineyard group (Table 3). In both years, the average berry weight was smallest in the SW group while berries from E and SE groups were the largest. Berry weight regularly increased from 30 dav to harvest, except in the E group in 2012, where berries reached a large size at 30 dav (Table 3). For this parameter, significant differences between years were observed (Table 3) but no interaction between group and year was observed. In 2012, Total Soluble Solids content (TSS) was similar for all groups at 30 dav; at harvest it achieved the highest value in SW (also in 2013), coherently with a lower berry weight. In 2013, SE and E vineyards had the lowest TSS at any sampling date (Table 3). In the SW and W vineyards, TSS was significantly higher in the wet and cool anomalous 2013 than in 2012 especially at the first two samplings; however, the seasonal trend of accumulation depended on both year and group (Table 3). The interaction between group and year was significant for TSS (Table 3). In both years, at harvest, SW grouped vineyards reached the highest $\mathrm{pH}$, and the lowest titratable acidity (Table 3). At 30 dav, the $\mathrm{pH}$ achieved by each group was similar in both years; afterwards, in 2012, an increase of $\mathrm{pH}$ larger than in 2013 was observed; this led to a significantly higher $\mathrm{pH}$ at harvest for all groups in 2012. Consistently with what was observed for $\mathrm{pH}$, titratable acidity was lower in 2012 than in 2013 at all sampling dates (Table 3). The interaction between group and year was significant for $\mathrm{pH}$ but not for titratable acidity. At all sampling dates, significant differences were observed among groups for malic and tartaric acid concentration. From the first sampling onwards, the must from $\mathrm{E}$ and $\mathrm{W}$ vineyards had the highest and the lowest malic acid concentration, respectively, in both years (Table 3). Furthermore, at 30 dav, malic acid achieved a similar concentration in both years, but its seasonal decrease was more accentuated in 2012 than in 2013 regardless of vineyard group; this led to significantly higher malic acid concentration at harvest in 2013. On the contrary, tartaric acid concentration was higher in 2012 than in 2013. On average, SE and E groups had the highest concentration of both acids, while SW and W had the lowest (Table 3). For both acids, the interaction between year and group was not significant. The berry anthocyanin concentration was highest in the cooler season (2013), and in both years in the vineyards of the cooler MUs (E and W groups); the concentration was higher from 30 dav onwards, regardless of year (Table 3). The anthocyanin concentration increased during ripening, peaking around 45 dav in both years, on average; however, in 2013 a greater synthesis in the early phases was followed by a final plateau in all vineyard groups. The differences among groups observed in the earlier phase were still evident at harvest even with different relationships among groups. In the case of the hottest vineyards (SW), and especially in the hottest year, the anthocyanin concentration at 30 dav was significantly lower than that expressed by the cooler vineyards even though there was no significant difference in TSS. The interaction between year and group was significant for anthocyanin concentration. 


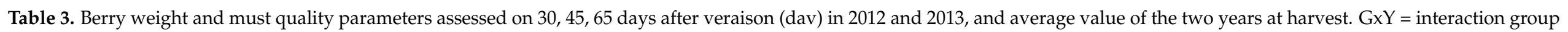
$\mathrm{x}$ year. $\mathrm{E}=$ vineyards facing east, $\mathrm{SE}=$ vineyards facing south-east, $\mathrm{SW}=$ vineyards facing south-west, $\mathrm{W}=$ vineyards facing west.

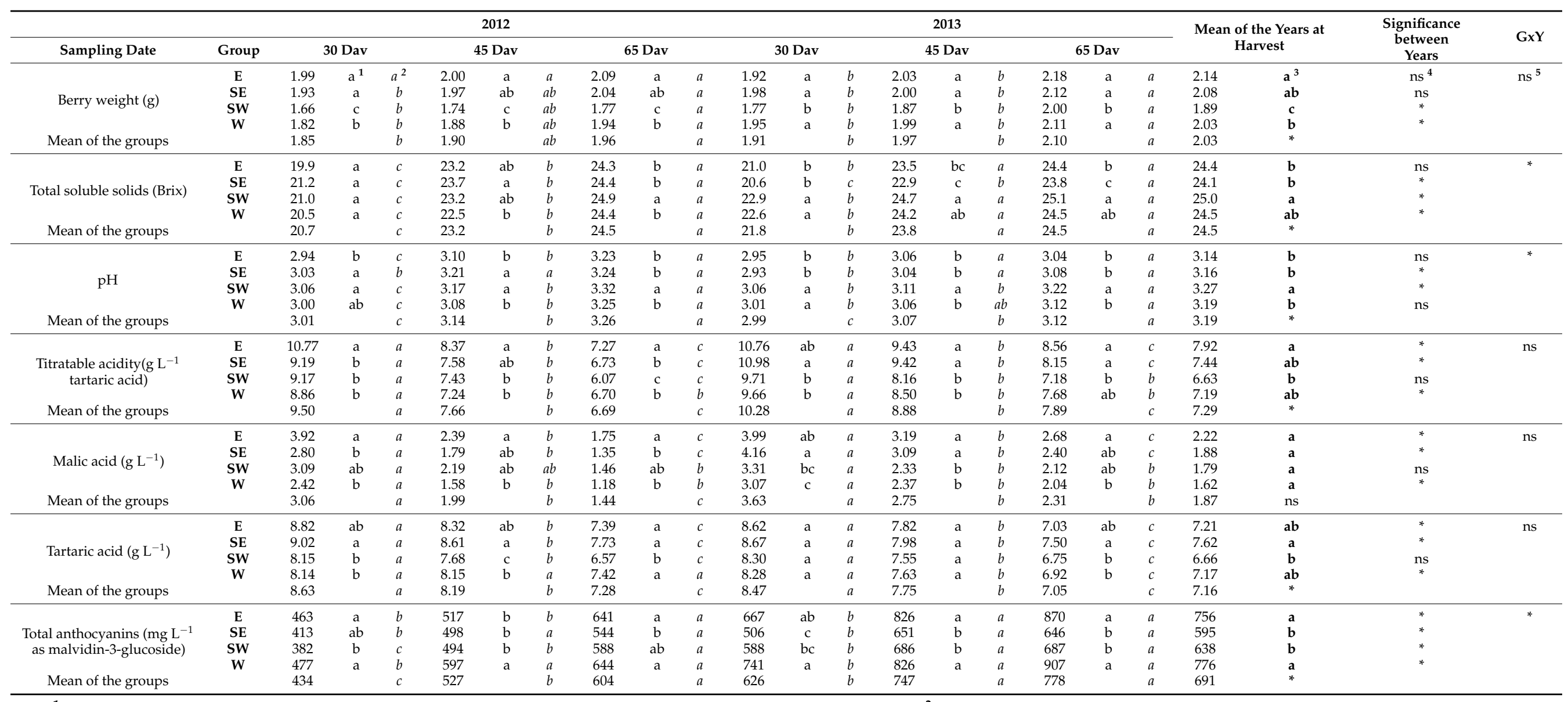

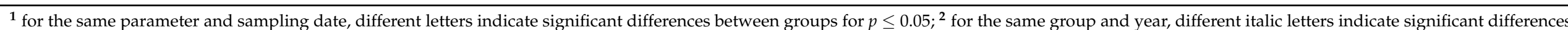

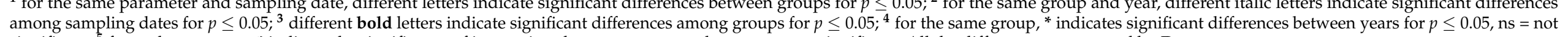
significant; ${ }^{5}$ for each parameter, ${ }^{*}$ indicate the significance of interactions between group and year, ns $=$ not significant. All the differences were tested by Duncan test. 
The differences between years highlighted by the ANOVA, were also confirmed by the PCA performed on the harvest values of the same variables. The first two components retained 71\% of the total variance (PC1 46\%; PC2 25\%). The separation of the two seasons was particularly evident along PC2 (Figure 5). This separation was mainly influenced by anthocyanin concentrations (eigenvectors of 0.95 ) and $\mathrm{pH}$ (eigenvectors of -0.71 ). The vineyards were distributed along PC1 due to total soluble solids (eigenvector $=0.85$ ), berry weight (eigenvector $=-0.73$ ), and malic acid concentration (eigenvector $=-0.55$ ). No clear vineyard grouping was evident in either of the two years; however, the vineyard dispersion along the first two PCs was wider in 2013 than in 2012 (Figure 5).

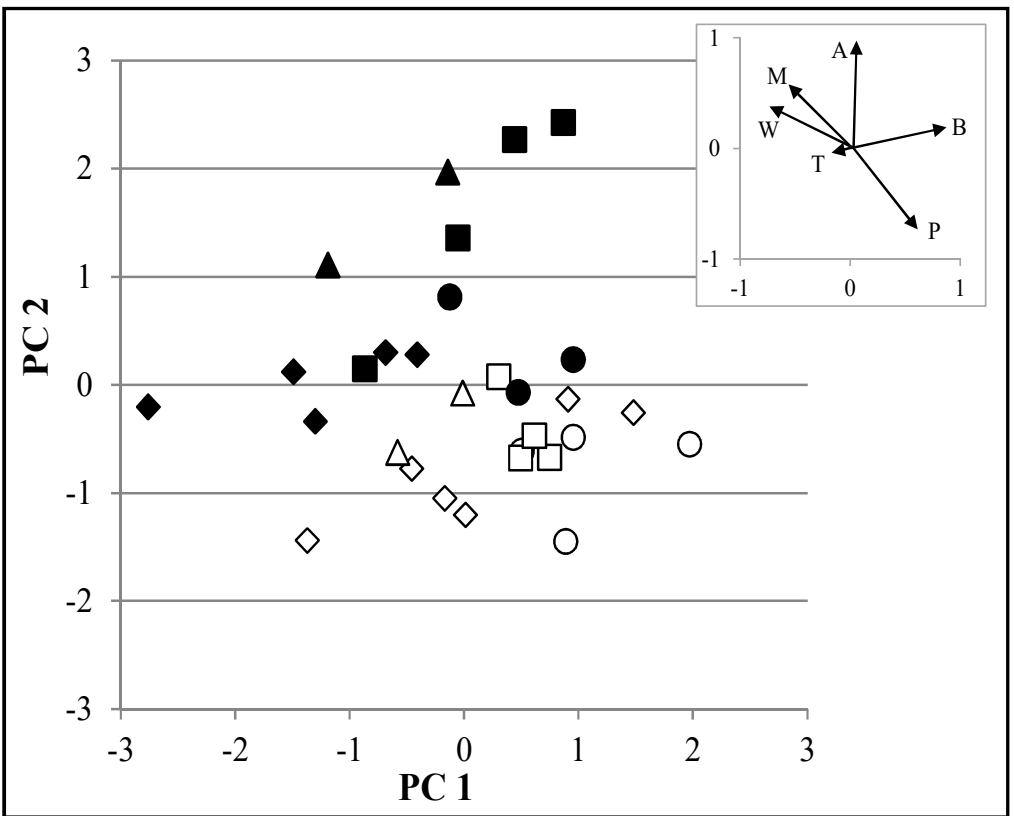

Figure 5. Distribution of the vineyards based on the PCA of must composition at harvest, with group discrimination by season: $2012(\Delta \mathrm{E} \diamond \mathrm{SE} \bigcirc \mathrm{SW} \square \mathrm{W}) ; 2013(\boldsymbol{E} \diamond \mathrm{SE} \bullet \mathrm{SW} \boldsymbol{\square})$ ). In the small box the values of the eigenvectors of the six variables included in the model are shown: $\mathrm{W}=$ berry weight, $\mathrm{B}=$ total soluble solids, $\mathrm{T}=$ titratable acidity, $\mathrm{p}=\mathrm{pH}, \mathrm{M}=$ malic acid, $\mathrm{A}=$ anthocyanins.

\subsection{Vine Vigor and Yield}

Yield components and vine vigor were influenced by group (Table 4). On average, yield, bunch weight, and pruning weight were lower in the SW group, yield per vine was higher in the SE group due to a higher number of bunches. In 2013, the values of the yield components were higher than in 2012 but not for all vineyard groups. In 2012, the Ravaz index was similar for all groups; however, in 2013 it was highest in the more productive SE group. The interaction between group and year was only significant for yield components and Ravaz index (Table 4). 
Table 4. Yield components assessed at harvest and vine vigor parameters assessed at winter pruning in 2012 and 2013 . Data corresponds to the mean values of the vineyards belonging to each group $(G)$ : $E=$ vineyards facing east, $S E=$ vineyards facing south-east, $\mathrm{SW}=$ vineyards facing south-west, $\mathrm{W}=$ vineyards facing west. $\mathrm{MU}=$ mesoclimatic units, $\mathrm{Y}=$ year, $\mathrm{G}=$ group, $\mathrm{GxY}=$ interaction group $\mathrm{x}$ year.

\begin{tabular}{|c|c|c|c|c|c|c|c|c|c|}
\hline & MU & G & & & & & $G$ & $\mathbf{Y}$ & GXY \\
\hline \multirow{4}{*}{$\begin{array}{l}\text { Yield/vine } \\
\quad(\mathrm{kg})\end{array}$} & \multirow{2}{*}{$\mathbf{L M}$} & $\mathbf{E}$ & 2.33 & $\mathrm{a}^{1}$ & 2.70 & $\mathrm{~b}^{1}$ & $b^{2}$ & \multirow{4}{*}{$* 3$} & \multirow{4}{*}{$* 3$} \\
\hline & & SE & 2.72 & $\mathrm{a}$ & 4.31 & $a$ & $a$ & & \\
\hline & SB & SW & 1.74 & $b$ & 1.50 & c & $c$ & & \\
\hline & B & $\mathbf{W}$ & 2.44 & a & 2.09 & $\mathrm{bc}$ & $b$ & & \\
\hline \multirow{4}{*}{$\begin{array}{c}\text { Bunch weight } \\
\text { (g) }\end{array}$} & \multirow{2}{*}{$\mathbf{L M}$} & E & 304 & a & 297 & b & $a$ & \multirow{4}{*}{ * } & \multirow{4}{*}{ * } \\
\hline & & $\mathrm{SE}$ & 282 & a & 399 & $\mathrm{a}$ & $a$ & & \\
\hline & SB & SW & 236 & $b$ & 246 & $b$ & $b$ & & \\
\hline & B & $\mathbf{W}$ & 299 & a & 322 & $\mathrm{ab}$ & $a$ & & \\
\hline \multirow{4}{*}{$\begin{array}{l}\text { Bunches per } \\
\text { vine (number) }\end{array}$} & \multirow{2}{*}{ LM } & E & 7.66 & $b$ & 8.82 & $b$ & $b$ & \multirow{4}{*}{ ns } & \multirow{4}{*}{ * } \\
\hline & & $\mathrm{SE}$ & 9.77 & a & 10.83 & $\mathrm{a}$ & $a$ & & \\
\hline & SB & SW & 7.51 & $\mathrm{~b}$ & 6.28 & C & $b$ & & \\
\hline & B & $\mathbf{W}$ & 8.21 & $\mathrm{~b}$ & 6.34 & C & $b$ & & \\
\hline \multirow{4}{*}{$\begin{array}{l}\text { Pruning } \\
\text { wood per } \\
\text { vine } \\
\text { (g) }\end{array}$} & \multirow{2}{*}{ LM } & E & 1041 & $a b$ & 896 & $\mathrm{a}$ & $a b$ & \multirow{4}{*}{ ns } & \multirow{4}{*}{ ns } \\
\hline & & SE & 1012 & $\mathrm{ab}$ & 997 & $\mathrm{a}$ & $a$ & & \\
\hline & SB & SW & 831 & $b$ & 694 & b & $b$ & & \\
\hline & B & $\mathbf{W}$ & 1142 & a & 912 & $\mathrm{a}$ & $a$ & & \\
\hline \multirow{4}{*}{$\begin{array}{c}\text { Shoot weight } \\
(\mathrm{g})\end{array}$} & \multirow{2}{*}{ LM } & E & 123 & $a b$ & 108 & $\mathrm{a}$ & $a$ & \multirow{4}{*}{ * } & \multirow{4}{*}{ ns } \\
\hline & & $\mathrm{SE}$ & 105 & $a b$ & 95 & $\mathrm{a}$ & $a$ & & \\
\hline & SB & SW & 102 & $b$ & 87 & $\mathrm{a}$ & $a$ & & \\
\hline & B & $\mathbf{W}$ & 136 & a & 105 & $\mathrm{a}$ & $a$ & & \\
\hline \multirow{4}{*}{ Ravaz index } & \multirow{2}{*}{$\mathbf{L M}$} & E & 2.46 & a & 3.13 & $b$ & $b$ & \multirow{4}{*}{$*$} & \multirow{4}{*}{ * } \\
\hline & & $\mathrm{SE}$ & 2.79 & a & 4.55 & $\mathrm{a}$ & $a$ & & \\
\hline & SB & SW & 2.38 & a & 2.22 & b & $b$ & & \\
\hline & B & $\mathbf{W}$ & 2.34 & a & 2.48 & b & $b$ & & \\
\hline
\end{tabular}

\footnotetext{
${ }^{1}$ For the same parameter and year, different letters indicate significant differences among groups for $p \leq 0.05$ according to the Duncan test.

2 For the same parameter, different italic letters indicate significant differences among groups regardless of the year, for $p \leq 0.05$ according to the Duncan test; ${ }^{3}$ significance of the differences between years $(\mathrm{Y})$ and of interaction between group and year $(\mathrm{GxY}){ }^{*}=\operatorname{significant}$ for $p \leq 0.05, \mathrm{~ns}=$ not significant.
}

\section{Discussion}

To understand the influence of topographic variability on climate at a meso scale level, a comparison was made among historical series of meteorological data recorded on five weather stations spread in the study area. Despite a wide seasonal variability of meteorological variables, the relationships among stations (and therefore among mesoclimatic units) remained constant over the years $[63,64]$. The current study, therefore, focused on the analysis of two bioclimatic indices (GDD and rainfall). These indices are known as main drivers of grapevine phenology and grape ripening and are expected to be impacted by climate change $[65,66]$. Based on historical variability of annual GDD and rainfall, three mesoclimatic units were identified: Serralunga Boscareto (SB), La Morra (LM) and Barolo (B). This partially confirmed the trend observed in a previous zoning study, although that study was done on a more limited database [52]. In the current study, the meteorological variables were not monitored in the individual vineyards. However, according to literature $[13,16,21,22,67]$, it is possible to hypothesize differences among both mesoclimatic units and vineyard groups due to differences in slope aspect, row orientation, elevation and intercepted solar radiation (Table 1). The study was carried out in two vintages which had very different weather conditions. This gave the opportunity to test whether the vintage may act synergistically with the site topography in influencing grape ripening. Further, due to the different conditions in the study years it was possible to extrapolate a better understanding of how climate change may impact berry quality, specifically in a topographically varied viticultural region. 
The SW vineyards were located at higher elevations and belonged to the warmest unit (SB) and, together with those facing SE, had the highest insolation. Contrary to expectation that temperature would decrease from an increase in elevation $[8,43]$, but in accordance with a study on Glera cv. [41], the SW group of vineyards in this study were not the coolest ones, evidencing that a higher elevation was not enough to make vineyards cooler. The $\mathrm{E}$ group of vineyards had the lowest insolation and was placed in the coolest and rainiest MU (LM); the SE group, located in the same MU, was warmer than E due to both the higher insolation and a row orientation that enhanced the interception of the sun's energy [22]. The vineyards of the $\mathrm{W}$ group, which had the same row orientation as the E vineyards, had a similar insolation, but were located in a warmer unit (B) (Figures 1 and 2). Despite differences, and following previous findings, all vineyard row orientations were favourable to the uptake of solar energy [22]; thus, in this study vineyard topography likely prevailed over row orientation in influencing the results.

As described, all the must quality parameters were significantly influenced by the MUs and season (Table 3) and for some of them the interaction between vineyard group and year was also significant (Tables 1 and 3). Berry ripening behaved in accordance with the MUs and the related values of temperature, insolation, and precipitation which were strongly influenced by slope aspect (Table 1 and Figure 3 ). This has been recently confirmed by a study carried out in a mountain wine-growing region, that revealed a direct relationship between the must sugar content and an index of "solar radiation identity" calculated on the base of vineyard topography features [7]. In LM's unit, berry weight, must acidity, and anthocyanin concentration were higher, whereas TSS and pH were lower when compared with the must quality of SB's unit (SW group), in particular. With the same insolation, the cooler conditions of the E vineyard favored the accumulation of malic acid and reduced its degradation compared to the $\mathrm{W}$ group and also enhanced the synthesis of anthocyanins. Although groups, SE and E, were in the same MU, the malic acid and anthocyanin concentrations in SE group of vineyards were lower than in E group likely because of the greater insolation of SE vineyards and the consequent greater number of daily hot hours. The lower concentration of anthocyanins also found in the SW group, particularly in 2012, was consistent with the high temperatures of the sites and the vintage; this finding complemented studies that observed lower anthocyanin concentration in cases of high temperature or high heat accumulation [12,35,37,38,68-70]. The results for SW grouped vineyards were only partially in agreement with what was observed in the Douro Valley, where a negative effect of altitude and south-west aspect was observed on berry volume and yield, but not on skin total anthocyanin [43]. This was likely due to the fact that the SB MU was warm despite a higher altitude. In the current study, the observed differences among groups in both TSS and anthocyanin concentration, were not completely explained by the size of berry mass. This observation supports the hypothesis that factors other than berry mass (e.g., water availability or topo-climatic condition) may influence berry metabolism and composition [71-73]. In 2013, at harvest, musts achieved higher TSS and acidity and a higher concentration of skin anthocyanin despite greater berry mass and similar vine vigor to 2012 (Tables 3 and 4). This indicated a different evolution of the individual compounds and not a different degree of grape ripening. This evidenced that in anomalously wet and cool seasons, such as 2013 in the area of the study, excellent qualitative results can be obtained in optimal topo-climatic locations.

In addition to the influence on berry weight and must quality that were attributed to grouping and year, the year influenced the yield but not the vine vigor. Yield variation also appeared be related to the group (Table 4). This produced some differences among groups with the Ravaz index in 2013; despite it remaining at generally low values [74], the Ravax index did not negatively impact grape quality. However, the findings were not sufficient to explain the must compositional differences among groups and to support the general idea that a greater crop per vine reduces grape quality or vice versa, at least not in the range of the yield of the studied vineyards. When the most productive vineyards (SE) were compared with the less productive ones (SW), it emerged that this was due to a 
higher bunch number per vine and a larger berry size and that this was true both in the driest and in the wettest year. In terms of composition, TSS and $\mathrm{pH}$ were higher in the less productive vineyards than in the most productive ones only in the wetter year; tartaric acid was higher in the most productive vineyards in both years, while malic acid and anthocyanins concentration was similar in both the groups in both years (Table 3). Since the intercepted radiation and soil AWC of these two groups were similar, these results may reflect the wetter and fresher conditions of the LM meso-climatic unit in which the most productive vineyards were located.

The PCA confirmed the differences induced by the year, but it mostly did not group the vineyards effectively (Figure 5). Furthermore, the PCA highlighted a greater dispersion of the vineyards in 2013 compared to 2012 along both PCs. Two reasons likely contributed to this result: (1) the greater variability of the seasonal characteristics of 2013 compared to 2012, and (2) the fact that the individual compounds were influenced differently by the vintage. In the cooler and rainy season, the differences among the vineyard groups were more accentuated than in the warmer and drier season; the PCA dispersion of vineyards within the same vintage were evident or not depending on the vineyard group and therefore on topography traits (Figure 5). This suggests that in the warmer years, the grape quality would be very similar in all the vineyards, and therefore the possibility of recognizing the geographical origin of the wines would be reduced, which, on the contrary, would be enhanced in the cooler and rainy years. With the expected temperature increases associated with climate change, the occurrence of unfavourable years due to thermal excesses and prolonged periods of drought will be more and more frequent [48]. Particularly in temperate and warm climate this is not positive as some of the key berry parameters (acids, anthocyanins, and $\mathrm{pH}$ ) can be impacted negatively in terms of quality output with increased temperatures [70].

All the results of this study confirmed the huge influence of the thermal conditions on the accumulation trend of many grape metabolites determining grape and wine quality $[28,29,35,70,75-77]$ and, in particular, their negative impact on the anthocyanin biosynthesis as observed in pot experiments $[34,35]$ and in field experiments $[11,17,36]$. Furthermore, it was also evidenced that not only the temperature itself, but also the vineyard topography together with the synergy between topo-climate and seasonal meteorological trends, plays an important role in affecting berry metabolism and grape ripening $[7,17,28,69]$. A highly varied topo-climate may determine different ripening pathways resulting in great differences in grape quality and in derived wines. As observed from the PCA analysis, this variation could be reduced as climate change evolves with warmer and dryer conditions being more frequent. This reduction in variation between regions within Barolo DOCG could lead to a reduction in typicality between these regions if mitigative strategies such as precision use of shade netting, leaf shading, or removal and cover cropping are not implemented by growers in an effort to preserve berry quality and typicity.

\section{Conclusions}

Even if a longer observation over more vintages would improve the robustness, the results of this study add elements to support the importance of the land topography in mediating the effect of the season and in influencing the quality of grape and wine production. This knowledge could be useful to help winegrowers to adapt site specific cultivation management strategies to consider, not only the weather conditions of the vintage but also the topography of their vineyards. This approach would be useful, firstly, to protect against or magnify seasonal variability and secondly, to develop management strategies for the expected long-term trends associated with climate change that affect grape ripening and may improve or decrease grape quality depending on topographic location. It would also be useful to improve pest management strategies with a more integrated and sustainable approach, especially if the microclimate were monitored at a low scale (vineyard or meso-climatic unit, for example). The use of tools typical of precision agriculture would make it easier to include the topographical characterization of a territory 
in zoning studies on this or other terroirs or on any farm zoning; this approach would increase the accuracy of knowledge and improve the precision of management techniques.

Supplementary Materials: The following are available online at https:/ / www.mdpi.com/article / 10.3390/agronomy11061142/s1, Table S1: Main soil chemical-physical properties of each vineyard according to soil horizons.

Author Contributions: Conceptualization and methodology S.G. and E.M.; investigation: E.M., S.G., F.P., M.G., and M.P.; data curation and writing-original draft preparation: E.M. and S.G.; writing-review and editing: A.W. and S.G. All authors have read and agreed to the published version of the manuscript.

Funding: This research was funded by Syngenta.

Institutional Review Board Statement: Not applicable.

Informed Consent Statement: Not applicable.

Data Availability Statement: Data used for Figures 2 and 3 are available to www.sistemapiemonte. it/agricoltura/ram/, accessed on 15 May 2021.

Acknowledgments: The authors would like to thank Fondazione Dalmasso for supporting the study; the wineries Azienda agricola Caronte, Azienda agricola Floris, Azienda agricola GD Vajra, Azienda agricola Giacomo Grimaldi, Azienda agricola Morra Diego, Azienda Agricola Voerzio, Azienda vitivinicola Paolo Scavino, Fontanafredda, Marchesi di Barolo, Sandrone Luciano, Vignetico s.a.a. for collaborating in the vineyard management; Bilab s.r.l. for collaborating in chemical analysis.

Conflicts of Interest: The authors declare no conflict of interest. The funders had no role in the design of the study; in the collection, analyses, or interpretation of data; in the writing of the manuscript, or in the decision to publish the results.

\section{References}

1. Van Leeuwen, C.; Seguin, G. The concept of terroir in viticulture. J. Wine Res. 2006, 17, 1-10. [CrossRef]

2. Gutiérrez-Gamboa, G.; Zheng, W.; De Toda, F.M. Strategies in vineyard establishment to face global warming in viticulture: A mini review. J. Sci. Food Agric. 2021, 101, 1261-1269. [CrossRef] [PubMed]

3. Seguin, G. 'Terroirs' and pedology of wine growing. Cell. Mol. Life Sci. 1986, Experientia 42, 861-873. [CrossRef]

4. Definition of Vitivinicultural "Terroir"; Resolution OIV/Viti 333/2010; O.I.V.: Tbilisi, Georgia, 2010.

5. Echeverría, G.; Ferrer, M.; Mirás-Avalos, J.M. Quantifying the relative impact of physical and human factors on the viticultural expression of terroir. Int. J. Environ. Agric. Res. 2017, 3, 12-25.

6. Karlik, L.; Marián, G.; Falt'an, V.; Havlíček, M. Vineyard zonation based on natural terroir factors using multivariate statisticsCase study Burgenland (Austria). OENO One 2018, 52, 105-117. [CrossRef]

7. Ferretti, C. Topoclimate and wine quality: Results of research on the Gewürztraminer grape variety in South Tyrol, northern Italy. OENO One 2021, 55, 313-335. [CrossRef]

8. Lino, T.; Scafidi, P.; Barbagallo, M.G. Effetti dell'altitudine e dell'orientamento dei filari sulla qualità dell'uva ed in particolare sulla componente fenolica della cv. Pinot Nero. Quad. Sci. Vitic. Enol. Univ. Torino 2007, 29, 113-124.

9. Fraga, H.; Malheiro, A.C.; Moutinho-Pereira, J.; Cardoso, R.M.; Soares, P.M.M.; Cancela, J.J.; Pinto, J.G.; dos Santos, J.C.A. Integrated Analysis of Climate, Soil, Topography and Vegetative Growth in Iberian Viticultural Regions. PLoS ONE 2014, 9, e108078. [CrossRef] [PubMed]

10. Brillante, L.; Mathieu, O.; Lévêque, J.; van Leeuwen, C.; Bois, B. Water status and must composition in grapevine cv. Chardonnay with different soils and topography and a mini meta-analysis of the $\delta 13 \mathrm{C} /$ water potentials correlation. J. Sci. Food Agric. 2017, 98, 691-697. [CrossRef] [PubMed]

11. Chorti, E.; Guidoni, S.; Ferrandino, A.; Novello, V. Effects of different cluster sunlight exposure levels on ripening and anthocyanin accumulation in Nebbiolo grapes. Am. J. Enol. Vitic. 2010, 61, 23-30.

12. Guidoni, S.; Cavalletto, S.; Bartolomei, S.; Mania, E.; Gangemi, L. Microclimatic aspects in vineyards with different vigor and exposure. Progrès Agric. Vitic. 2011, 17, 547-550.

13. Matese, A.; Crisci, A.; Di Gennaro, S.F.; Primicerio, J.; Tomasi, D.; Marcuzzo, P.; Guidoni, S. Spatial variability of meteorological conditions at different scales in viticulture. Agric. For. Meteorol. 2014, 189-190, 159-167. [CrossRef]

14. Andreoli, V.; Bertoni, D.; Cassardo, C.; Ferrarese, S.; Francone, C.; Spanna, F. Analysis of micrometeorological conditions in Piedmontese vineyards. Ital. J. Agrometeorol. 2018, 2, 27-40. [CrossRef]

15. Brillante, L.; Martínez-Luscher, J.; Yu, R.; Plank, C.M.; Sanchez, L.; Bates, T.L.; Brenneman, C.; Oberholster, A.; Kurtural, S.K. Assessing Spatial Variability of Grape Skin Flavonoids at the Vineyard Scale Based on Plant Water Status Mapping. J. Agric. Food Chem. 2017, 65, 5255-5265. [CrossRef] [PubMed] 
16. Bois, B.; Joly, D.; Quénol, H.; Pieri, P.; Gaudillère, J.-P.; Guyon, D.; Saur, E.; Van Leeuwen, C. Temperature-based zoning of the Bordeaux wine region. OENO One 2018, 52, 1-16. [CrossRef]

17. Blank, M.; Hofmann, M.; Stoll, M. Seasonal differences in Vitis vinifera L. cv. Pinot noir fruit and wine quality in relation to climate. OENO One 2019, 53, 189-203. [CrossRef]

18. Dumas, V.; Lebon, E.; Morlat, R. Différenciations mésoclimatiques au sein du vignoble alsacien. J. Int. Sci. Vigne Vin 1997, 31, 1-9.

19. Kumar, L.; Skidmore, A.K.; Knowles, E. Modelling topographic variation in solar radiation in a GIS environment. Int. J. Geogr. Inf. Sci. 1997, 11, 475-497. [CrossRef]

20. Intrieri, C.; Poni, S.; Rebucci, B.; Magnanini, E. Row orientation effects on whole-canopy gas exchange of potted and field-grown grapevines. Vitis 1998, 37, 147-154.

21. Van Leeuwen, C.; Friant, P.; Choné, X.; Tregoat, O.; Koundouras, S.; Dubourdieu, D. Influence of climate, soil and cultivar on terroir. Am. J. Enol. Vitic. 2004, 55, 207-217.

22. Hunter, J.; Volschenk, C.; Zorer, R. Vineyard row orientation of Vitis vinifera L. cv. Shiraz/101-14 Mgt: Climatic profiles and vine physiological status. Agric. For. Meteorol. 2016, 228-229, 104-119. [CrossRef]

23. Naylor, A.P.; Creasy, G.L.; Trought, M.C.T.; van Hanen, L. The effects of row orientation and fruit exposure on the juice composition of Sauvignon blanc (Vitis vinifera L.). In Proceedings of the Fifth International Symposium on Cool Climate Viticulture and Enology, Melbourne, Australia, 16-20 January 2000.

24. Guidoni, S.; Ferrandino, A.; Novello, V. Effects of seasonal and agronomical practices on skin anthocyanin profile of Nebbiolo grapes. Am. J. Enol. Vitic. 2008, 59, 22-29.

25. Falcão, L.D.; Brighenti, E.; Rosier, J.-P.; Bordignon-Luiz, M.T.; Burin, V.M.; Chaves, E.S.; Vieira, H.J. Vineyard altitude and mesoclimate influences on the phenology and maturation of Cabernet-Sauvignon grapes from Santa Catarina State. OENO One 2010, 44, 135. [CrossRef]

26. Cugnetto, A.; Santagostini, L.; Rolle, L.; Guidoni, S.; Gerbi, V.; Novello, V. Tracing the "terroirs" via the elemental composition of leaves, grapes and derived wines in cv Nebbiolo (Vitis vinifera L.). Sci. Hortic. 2014, 172, 101-108. [CrossRef]

27. Echeverría, G.; Ferrer, M.; Mirás-Avalos, J. Effects of soil type on vineyard performance and berry composition in the Río de la Plata Coast (Uruguay). OENO One 2017, 51, 251-261. [CrossRef]

28. Asproudi, A.; Petrozziello, M.; Cavalletto, S.; Guidoni, S. Grape aroma precursors in cv. Nebbiolo as affected by vine microclimate. Food Chem. 2016, 211, 947-956. [CrossRef]

29. Asproudi, A.; Petrozziello, M.; Cavalletto, S.; Ferrandino, A.; Mania, E.; Guidoni, S. Bunch Microclimate Affects Carotenoids Evolution in cv. Nebbiolo (V. vinifera L.). Appl. Sci. 2020, 10, 3846. [CrossRef]

30. Hunter, J.J.; Volschenk, C.G.; Booyse, M. Vineyard row orientation and grape ripeness level effects on vegetative and reproductive growth characteristics of Vitis vinifera L. cv. Shiraz/101-14 Mgt. Eur. J. Agron. 2017, 84, 47-57. [CrossRef]

31. Hunter, J.J.; Volschenk, C.G. Chemical composition and sensory properties of non-wooded and wooded Shiraz (Vitis vinifera L.) wine as affected by vineyard row orientation and grape ripeness level. J. Sci. Food Agric. 2018, 98, 2689-2704. [CrossRef] [PubMed]

32. Guidoni, S.; Cavalletto, S.; Gangemi, L.; Mania, E.; Ferrandino, A.; Giacosa, S. Variabilità del microclima del vigneto e maturazione dell'uva Nebbiolo. Quad. Sci. Vitic. Enol. 2013, 32, 325-330.

33. Marais, J.; Calitz, F.; Haasbroek, P. Relationship Between Microclimatic Data, Aroma Component Concentrations and Wine Quality Parameters in the Prediction of Sauvignon blanc Wine Quality. S. Afr. J. Enol. Vitic. 2017, 22, 22-26. [CrossRef]

34. Yamane, T.; Jeong, S.T.; Goto-Yamamoto, N.; Koshita, Y.; Kobayashi, S. Effects of temperature on anthocyanin biosynthesis in grape berry skins. Am. J. Enol. Vitic. 2006, 57, 54-59.

35. Mori, K.; Goto-Yamamoto, N.; Kitayama, M.; Hashizume, K. Effect of high temperature on anthocyanin composition and transcription of flavonoid hydroxylase genes in 'Pinot noir' grapes (Vitis vinifera). J. Hortic. Sci. Biotechnol. 2007, 82, 199-206. [CrossRef]

36. Tarara, J.M.; Lee, J.; Spayd, S.E.; Scagel, C.F. Berry temperature and solar radiation alter acylation, proportion, and concentration of anthocyanin in Merlot grapes. Am. J. Enol. Vitic. 2008, 59, 235-247.

37. Azuma, A.; Yakushiji, H.; Koshita, Y.; Kobayashi, S. Flavonoid biosynthesis-related genes in grape skin are differentially regulated by temperature and light conditions. Planta 2012, 236, 1067-1080. [CrossRef] [PubMed]

38. Sadras, V.; Morán, M. Elevated temperature decouples anthocyanins and sugars in berries of Shiraz and Cabernet Franc. Aust. J. Grape Wine Res. 2012, 18, 115-122. [CrossRef]

39. Scafidi, P.; Pisciotta, A.; Patti, D.; Tamborra, P.; Di Lorenzo, R.; Barbagallo, M.G. Effect of artificial shading on the tannin accumulation and aromatic composition of the Grillo cultivar (Vitis vinifera L.). BMC Plant Biol. 2013, 13, 175. [CrossRef]

40. Orte, M.P.H.; Concejero, B.; Astrain, J.; Lacau, B.; Cacho, J.; Ferreira, V. Influence of viticulture practices on grape aroma precursors and their relation with wine aroma. J. Sci. Food Agric. 2014, 95, 688-701. [CrossRef] [PubMed]

41. Alessandrini, M.; Gaiotti, F.; Belfiore, N.; Matarese, F.; D'Onofrio, C.; Tomasi, D. Influence of vineyard altitude on Glera grape ripening (Vitis vinifera L.): Effects on aroma evolution and wine sensory profile. J. Sci. Food Agric. 2017, 97, 2695-2705. [CrossRef] [PubMed]

42. Ferrer, M.; Echeverría, G.; Miras-Avalos, J.M. Meteorological Conditions: Influence on Yield, Sanitary Status and Grape Composition. Int. J. Environ. Agric. Res. 2017, 3, 16-27. [CrossRef] 
43. Oliveira, A.A.; Correia, M.J. Influence of elevation and slope exposure upon productivity and must quality of Touriga Nacional (sub-region of Douro superior). J. Int. Sci. Vigne Vin 2008, 42, 73-78. [CrossRef]

44. Rienth, M.; Lamy, F.; Noll, D.; Lorenzini, F.; Viret, O.; Zufferey, V. An example of a vine-physiology based fine-scale terroir study in the AOC Lavaux-region in Switzerland. E3S Web Conf. 2018, 50, 02011. [CrossRef]

45. Roullier-Gall, C.; Boutegrabet, L.; Gougeon, R.D.; Schmitt-Kopplin, P. A grape and wine chemodiversity comparison of different appellations in Burgundy: Vintage vs terroir effects. Food Chem. 2014, 152, 100-107. [CrossRef] [PubMed]

46. Pinu, F.R.; Tumanov, S.; Grose, C.; Raw, V.; Albright, A.; Stuart, L.; Villas-Boas, S.G.; Martin, D.; Harker, R.; Greven, M. Juice Index: An integrated Sauvignon blanc grape and wine metabolomics database shows mainly seasonal differences. Metabolomics 2019, 15, 3. [CrossRef] [PubMed]

47. Rienth, M.; Lamy, F.; Schoenenberger, P.; Noll, D.; Lorenzini, F.; Viret, O.; Zufferey, V. A vine-physiology based terroir study in the AOC Lavaux-region in Switzerland. OENO One 2020, 54, 863-880. [CrossRef]

48. Santos, J.A.; Fraga, H.; Malheiro, A.C.; Moutinho-Pereira, J.; Dinis, L.-T.; Correia, C.; Moriondo, M.; Leolini, L.; DiBari, C.; Costafreda-Aumedes, S.; et al. A Review of the Potential Climate Change Impacts and Adaptation Options for European Viticulture. Appl. Sci. 2020, 10, 3092. [CrossRef]

49. Guidoni, S.; Petrella, F.; Giovannozzi, M. The lands of Barolo and Barbaresco. The complexity of Piedmont soils. Tong 2013, 16, 23-28.

50. Masnaghetti, A. Barolo MGA. Enciclopedia delle Grandi Vigne del Barolo; Masnaghetti, A., Ed.; ENOGEA: Monza, Italy, $2015 ;$ p. 407.

51. Kottek, M.; Grieser, J.; Beck, C.; Rudolf, B.; Rubel, F. World Map of the Köppen-Geiger climate classification updated. Meteorol. Z. 2006, 15, 259-263. [CrossRef]

52. Gerbi, V.; Zeppa, G.; Rolle, L.; Ubigli, M.; Alessandria, F. Barolo. Studio per la Caratterizzazione del Territorio, delle Uve e dei Vini Dell'area di Produzione. Regione Piemonte; Supplemento al n. 24 di “Quaderni della Regione Piemonte-Agricoltura”; IRIS: Torino, Italy, 2000; p. 191.

53. IPLA. Manuale di Campagna per il Rilevamento e la Descrizione dei Suoli; Rev. 03/marzo 2006/DS01P11; IPLA: Torino, Italy, 2003.

54. Soil Survey Staff. Soil Taxonomy: A Basic System of Soil Classification for Making and Interpreting Soil Surveys, 2nd ed.; U.S. Department of Agriculture Handbook 436; Natural Resources Conservation Service: Washington, DC, USA, 1999. Available online: www.nrcs.usda.gov/wps/portal/nrcs/main/soils/survey/class/taxonomy/ (accessed on 15 May 2021).

55. MiPAF. Metodi di Analisi Chimica del Suolo; Angeli, F., Ed.; MiPAF: Rome, Italy, 2000; p. 536.

56. Walkley, A.J.; Black, I.A. Estimation of soil organic carbon by the chromic acid titration method. Soil Sci. 1934, 37, 29-38. [CrossRef]

57. Gazzetta Ufficiale della Repubblica Italiana. Serie Generale n. 204 del 2 Settembre 1997; Supplemento Ordinario n. 173. Approvazione dei "Metodi Ufficiali di Analisi Fisica del Suolo"; Repubblica Italiana: Rome, Italy, 1997.

58. USDA. Soil Survey Laboratory Methods Manual; Report n. 42, Version 3; USDA: Washington, DC, USA, 1996; p. 716. Available online: https:/ / www.nrcs.usda.gov/wps/portal/nrcs/detail/soils/ref/?cid=nrcs142p2_054247 (accessed on 15 May 2021).

59. Schneider, A.; Gerbi, V.; Redoglia, M. A rapid HPLC method for separation and determination of major organic acids in grape musts and wines. Am. J. Enol. Vitic. 1987, 38, 151-155.

60. Di Stefano, R.; Cravero, M.C. Metodi per lo studio dei polifenoli dell'uva. Riv. Vitic. Enol. 1991, 2, 37-45.

61. Glories, Y.; Augustin, M. Maturité phénolique du raisin, conséquences technologiques: Application aux millésimes 1991 et 1992. J. Tech. CIVB 1993, F, 56-61.

62. Cagnasso, E.; Caudana, A.; Rolle, L.; Gerbi, V. Contributo allo studio allo studio della maturità fenolica in uve piemontesi. Quad. Vitic. Enol. Univ. Torino 2003, 26, 61-80.

63. Mania, E. Valutazioni Interdisciplinari per la Valorizzazione del Sistema Vigneto in Contesto Collinare. Ph.D. Thesis, Università di Torino, Torino, Italy, 2017; p. 184.

64. Mania, E.; Gangemi, L.; Piazzi, M.; Guidoni, S. Geographical features such as slope and exposure are terroir elements influencing grape quality. In Proceedings of the XIIth International Terroir Congress 2018, Zaragoza, Spain, 18-22 June 2018 ; pp. $484-487$.

65. Jones, G.V.; White, M.A.; Cooper, O.R.; Storchmann, K. Climate Change and Global Wine Quality. Clim. Chang. 2005, 73, 319-343. [CrossRef]

66. Keller, M. Managing grapevines to optimise fruit development in a challenging environment: A climate change primer for viticulturists. Aust. J. Grape Wine Res. 2010, 16, 56-69. [CrossRef]

67. Makowski, K. The Daily Temperature Amplitude and Surface Solar Radiation. Ph.D. Thesis, University of Zurich, Zurich, Switzerland, 2009; p. 95.

68. Nicholas, K.A.; Matthews, M.A.; Lobell, D.B.; Willits, N.H.; Field, C.B. Effect of vineyard-scale climate variability on Pinot noir phenolic composition. Agric. For. Meteorol. 2011, 151, 1556-1567. [CrossRef]

69. De Oliveira, A.F.; Mercenaro, L.; Del Caro, A.; Pretti, L.; Nieddu, G. Distinctive Anthocyanin Accumulation Responses to Temperature and Natural UV Radiation of Two Field-Grown Vitis vinifera L. Cultivars. Molecules 2015, 20, 2061-2080. [CrossRef] [PubMed]

70. Rienth, M.; Vigneron, N.; Darriet, P.; Sweetman, C.; Burbidge, C.; Bonghi, C.; Walker, R.P.; Famiani, F.; Castellarin, S.D. Grape Berry Secondary Metabolites and Their Modulation by Abiotic Factors in a Climate Change Scenario-A Review. Front. Plant Sci. 2021, 12, 643258. [CrossRef] [PubMed]

71. Roby, G.; Harbertson, J.F.; Adams, D.A.; Matthews, M.A. Berry size and vine water deficits as factors in winegrape composition: Anthocyanins and tannins. Aust. J. Grape Wine Res. 2004, 10, 100-107. [CrossRef] 
72. Walker, R.R.; Blackmore, D.H.; Clingeleffer, P.R.; Kerridge, G.H.; Rühl, E.H.; Nicholas, P.R. Shiraz berry size in relation to seed number and implications for juice and wine composition. Aust. J. Grape Wine Res. 2005, 11, 2-8. [CrossRef]

73. Barbagallo, M.; Guidoni, S.; Hunter, J. Berry Size and Qualitative Characteristics of Vitis vinifera L. cv. Syrah. S. Afr. J. Enol. Vitic. 2016, 32, 129-136. [CrossRef]

74. Smart, R.; Dick, J.K.; Gravett, I.M.; Fisher, B. Canopy Management to Improve Grape Yield and Wine Quality. S. Afr. J. Enol. Vitic. 2017, 11, 3-17. [CrossRef]

75. Lakso, A.N.; Kliewer, W.M. The Influence of Temperature on Malic Acid Metabolism in Grape Berries: I. Enzyme responses. Plant Physiol. 1975, 56, 370-372. [CrossRef] [PubMed]

76. Spayd, S.E.; Tarara, J.M.; Mee, D.L.; Ferguson, J.C. Separation of sunlight and temperature effects on the composition of Vitis vinifera cv. Merlot Berries. Am. J. Enol. Vitic. 2002, 53, 171-182.

77. He, F.; Mu, L.; Yan, G.-L.; Liang, N.-N.; Pan, Q.-H.; Wang, J.; Reeves, M.J.; Duan, C.-Q. Biosynthesis of Anthocyanins and Their Regulation in Colored Grapes. Molecules 2010, 15, 9057-9091. [CrossRef] [PubMed] 